\title{
DESIGN ROTOR TURBINE HYBRID OF PV-PICOHYDRO POWER PLANT AS ENERGY SOURCES FOR RURAL AREA IN INDONESIA
}

\author{
TITO SHANTIKA ${ }^{\mathbf{1}}$, TRI SIGIT PURWANTO ${ }^{2} \&$ MARTIN GARNIDA ${ }^{\mathbf{3}}$ \\ ${ }^{1,2}$ Research Scholars, Department of Mechanical Engineering, Institute Teknologi Nasional Bandung, Indonesia \\ ${ }^{3}$ Students, Department of Mechanical Engineering, Institute Teknologi Nasional Bandung, Indonesia
}

\begin{abstract}
In Indonesia, especially in rural areas, the potential of low head river and sunlight is still quite abundant energy source; these can be used as a source of electricity on a small scale such as picohydro and solar energy. The rural areas are usually far from the electricity network, so that a power plant off grid is sufficient enough for a house. One component of the picohydro generator is a turbine, and so, this research is designed with dimensions of turbine according to flow condition of the river in West Java Indonesia. The design of the turbine starts with assessing the water flow in the river in the country side, and then determining the design specifications, followed by designing the turbine details with theoretical and simulation approach. The generator that will be used has 12 Volt 500 rpm, the designed power has minimum of 100 watts. The results of the design obtained a Kaplan turbine with a 4 degree angle of attack, blade diameter $217 \mathrm{~mm}$. The maximum stress 5,9 MPa, this occurs in the area between the hub and turbine blade rotors, with thickness 2 mm and material blade used aluminum Alloy.
\end{abstract}

KEYWORDS: Power Plant, Turbine, Runner \& Picohydro

Received: Jan 03, 2020; Accepted: Jan 23, 2020; Published: Apr 30, 2020; Paper Id.: IJMPERDJUN202021

\section{INTRODUCTION}

Indonesia is a country that has many advantages with respect to geographical position. As atropics country, Indonesia has two seasons; dry season from November to March and rainy season from April to October (BPS, 2016), and also has many advantages of having many renewable energy sources; these are solar and hydro energy.

On the other hand, Indonesia still has energy problems, which is dependent on fossil energy (96\%). Utilization of new renewable energy is still limited because of constrained investment costs, and hence only largecapacity power plants are built. The utilization of renewable energy sources with small capacity in Indonesia is still limited, because of its relative high cost and low efficiency (DEN, 2014). One solution to this problem is to combine two or more renewable energy sources into a power plant called a Hybrid generator.

In Indonesia, especially in West Java province, there is a high potential to use solar energy and low head hydropower, especially at irrigation channels. Therefore, solar and hydro energy do still have huge potential resources. In some areas, micro hydro power plants are installed, but yet large capacity of the micro hydro is still unexploited (Erinofiardi, et all, 2017). Hence, it has a potential to build a hybrid power plant that combines solar energy and small-scale hydropower (picohydro).

The development of hybrid power plants is very growing fast due to the increasing electricity demand and it has quite abundant potential, such as it has been mentioned by Ratnata et all, (2017) (Ratnata, et all, 2018), Pico 
Hydro prototype - Solar Photovoltaic Hybrid System are developed in the two stages, the first prototype-1 has been developed a capacity 100 - 200 watts, second stage 500-1000 watts of capacity.

The other important parameter, the development of hybrid power plants is the economic factor. From the study engineering economics for Micro Hydro Turbine and PV, for electricity generator, the cost of hybrid system with $5 \mathrm{~kW}$ is 9.21 US Dollar/kWh (Bhumkittipich \& Bhumkittipich, 2013). Similar study was published by World Bank for the cost of generating Picohydro projects for several types of power plants. Picohydro is the smallest generation generator with around 10- 18 US cent / kWh (ESMAP, 2007). And also Phrakonkham (2012) compared with that of the system sizing for hybrid system of the pico/micro hydroelectric turbines, PV panels, energy storage device and a backup fuel generator, and the result is hydroelectric turbines, the hybrid system has very low overall cost of energy, and also they are suitable to be used in remote rural villages. It is a simple technology, and hence it is not difficult to maintain (Phrakonkham, et all, 2012).

Picohydro is a type of small-scale water energy generator that consumes below $5 \mathrm{~kW}$. Classification of plants utilizing water / hydro energy can be distinguished based on the generated power capacity (Sopian \& Razak, 2009). The combination of solar energy and small hydropower can utilize solar energy and irrigation flow which will be up to 0.5 meter deep. A potential irrigation is found in West Java. Figure 1 shows irrigation facilities in West Java. The estimate of the power plant is expected to be used for the needs of one house.

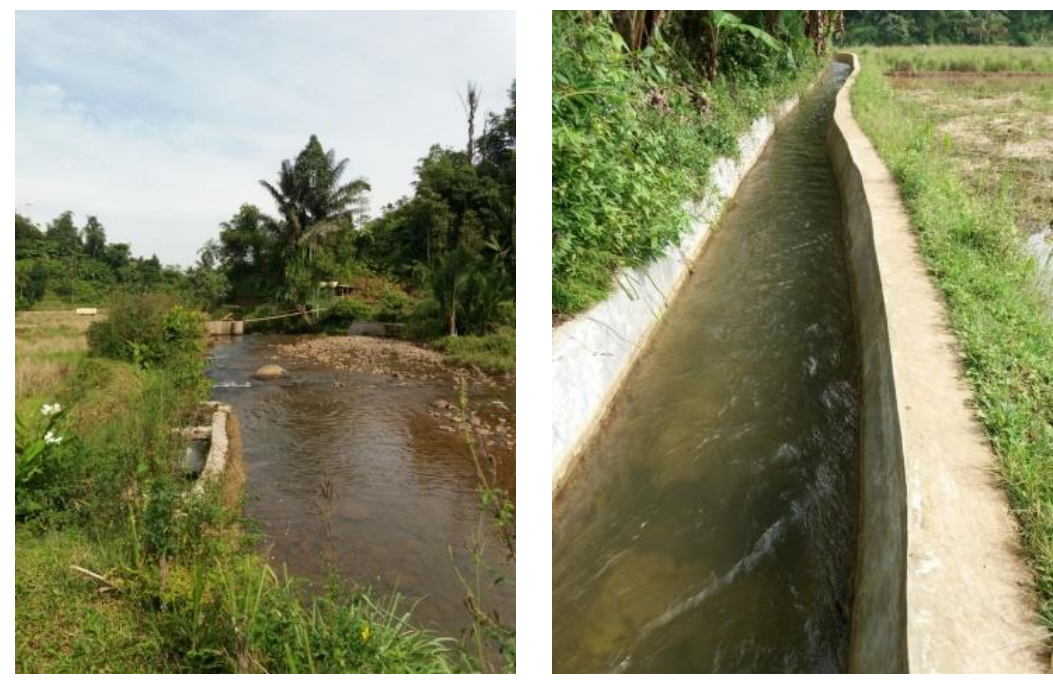

Figure 1: Hydro Power Resources in West Java Indonesia.

In this paper, investigation of hybrid power plant is presented, especially design of hybrid solar and picohydro. The hybrid PV-picohydro will be developed for rural area. The power plant will be installed as a floating position on the river and mounted with two slings attached at river side (Shantika \& Hartawan, 2017).

The power plant consists of several components; picohydro units, solar panels, control units, batteries, monitoring and collecting data systems, main frames and float device. A Picohydro unit is composed of generator, runner, housing, vane gate etc. This paper will focus on runner design part of turbine of picohydro suitable for flow conditions in irrigation river in Western Java, Indonesia. Other component generator was developed in the previous study. The generator was brushless with permanent magnet type designed for 200W, $500 \mathrm{rpm}$ and 12 volt specification (Shantika \& Hartawan, 2018). Control device, collecting data and monitoring system was used in nRF24L01 and Arduino (Hartawan, et all, 2018). The runner design was used as a theoretical approach in accordance with the design specifications with parameter 
constraints obtained from the survey results of several rivers in West Java, while the calculation of stresses that occur in the blade will use a stress simulation approach utilizing software. The software analysis obtained resulting optimum main dimension of runner material.

\section{RESEARCH METHOD}

The research was conducted in several stages; the first step is to measure the condition of the irrigation river in West Java, so that the average velocity and depth of the river were obtained. Then design specifications are determined according to the conditions of the energy source, and then design of dimensions using the theoretical approach. Furthermore, stress analysis was carried out by using simulation software, so that the thickness and material of the blade can be determined.

The main parameter of turbine blade design is blade angle. Turbine blade angle affect on rotation, torque and power of the turbine. The curve of the blade angle is calculated based on the velocity triangle, the flow of water flowing through the inlet stator blade and flow in to the rotor blade are shown in the figure 2a. The velocity relationship can be drawn to the velocity triangle, as shown in the figure $2 \mathrm{~b}$. With $\alpha_{1}$ and $\alpha_{2}$ is inlet and outlet angle stator in degree, $\beta_{1}$ and $\beta_{2}$ is inlet and outlet angle rotor in degree, $\mathrm{Q}$ is flow rate $\left(\mathrm{m}^{3} / \mathrm{s}\right), \omega$ is angular velocity $(\mathrm{rad} / \mathrm{s}), \mathrm{W}$ is relative water velocity trough blade $(\mathrm{m} / \mathrm{s}), \mathrm{U}$ is Linier velocity blade $(\mathrm{m} / \mathrm{s})$ and $\mathrm{C}$ is absolute velocity $(\mathrm{m} / \mathrm{s})(\mathrm{Grant}, 2007)$.

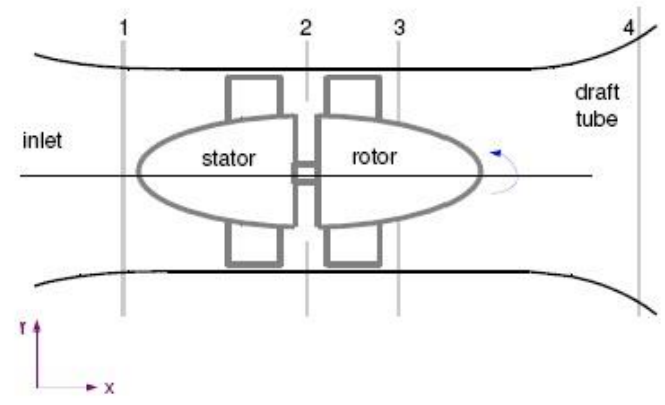

(a)

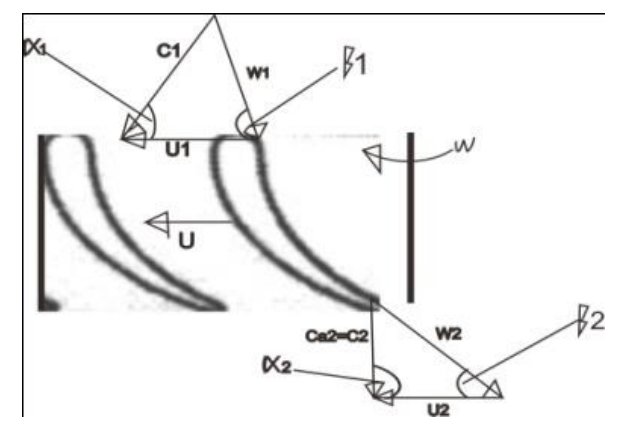

(b)

Figure 2: (a)Turbine Cross Section, (b) Triangle of Velocity(Grant, 2007).

The euler equation on turbine engines for output power is

$$
H=\frac{U_{1} \cdot C_{U_{1}}-U_{2} C_{w 2}}{g}
$$

From the speed triangle, the flow speed approaching the turbine blade is $V_{2}=\frac{W_{1} \cdot A_{1}}{A_{2}}$, absolute velocity is $C_{a}=\frac{Q_{1}}{A_{1}}$, and relative velocity is $C_{\mathrm{u} 1}=\frac{\mathrm{Hg} g}{U}$. The rotation direction for a positive angle requires of flow $\beta_{1}$ entering from the rotor and $\beta_{2}$ coming out of the stator, so that the equation:

$$
\begin{aligned}
& \beta_{1}=\tan ^{-1}\left(\frac{c_{m 1}}{c_{11}-U_{1}}\right) \\
& \beta_{2}=\tan ^{-1}\left(\frac{c_{m 2}}{c_{w 2}-U_{2}}\right)
\end{aligned}
$$

The amount of head and turbine inlet (Qin) is determined based on theoretical calculations which will become parameters in obtaining the power to be designed, the turbine head can be calculated with $H_{\text {source }}=\frac{v_{\text {smngaĩ }}^{2}}{2 \cdot \mathrm{g} g}$, inlet flow rate 
is $Q_{\text {in }}=\frac{P}{\mathrm{Pg} \cdot \mathrm{H}}$, and the water discharge flow rate trough turbine blade is $Q_{2}=V_{2} \cdot A_{\text {blade }}$. Specific rotational speed of the turbine is calculated using equations:

$$
\mathrm{n}_{s}=\frac{\mathrm{n} \sqrt{\mathrm{N}}}{\mathrm{H}^{\frac{1}{4}}}
$$

The energy losses that occur in the pipe due to incoming water flow can be major head losses or minor losses, water hammer, cavitation, viscosity, etc. However, picohydro flow losses that occur are minor head losses. If there are major head losses, the probability is very small. Minor head losses occur due to a collision between the flows of water entering the pipe regarding the blade. The size of minor head losses and turbine efficiency refers to the design that has previously been carried out with the title "Application and Analysis of Picohydro Power Plants with Turbine Propeller Open Flume TC 60 and 100 VA One Phase Synchronous Generator at UPI Bandung" (Nugraha \& Waluyo, 2013). Then, the design value of minor head losses is $4 \%$ and the design turbine efficiency is $85 \%$. This data will later become a reference in the design of portable picohydro.

Forces can be calculated based on the flow of water through the runner blade. The flow of the blade can make a lifting force $F_{L}=\frac{1}{2} C_{L} \rho A W_{2}^{2}$ and drag Force $F_{D}=\frac{1}{2} C_{D} \rho A W_{2}^{2}$, Where $C_{\mathrm{L}}=2 \sin \varphi \cos \varphi$ and $\mathrm{C}_{\mathrm{D}}=2$ sin ${ }^{2} \varphi, \mathrm{A}$ is blade area (m3) and $\varphi$ is angle of attack in degree (Simpson \& Williams, 2011).

\section{RESULTS AND DISCUSSIONS}

From data survey of several rivers for agricultural irrigation in West Java, Indonesia obtained the speed and depth of river, which was around $1-3.75 \mathrm{~m} / \mathrm{s}$ and 30-60 cm. The width of the river varied from 1 to 8 meters. During that seasonal time, the river conditions were dry, so that the condition of the water flows in the river was in the lower point of the water flow.

The Hybrid PV-picohydro power plant concept is planned for a floating system with dimensions not exceeding 1.5 meters and length 2 meters so that it can be carried easily. The electricity generator is used for one house Picohydro power off grid system 100 watts minimum and $200 \mathrm{Wp}$ solar cells.


Figure 3: Hybrid PV-Picohydro Power Plant Concept.

Picohydro is planned to be floated with diameters not exceeding 1 meter, it can be carried and assembly easily. The water flows through horizontal to turbine blade where power is obtained from the head of water speed. The water flow is planned to enter a channel and then rotate the turbine on the channel. The inlet diameter channel/penstock is designed 
greater than outlet diameter so that it can increase the speed of water that is passed through the turbine blade. The guide vane is planned to be in front of the blade in a same direction of the water flow.

These have limitations pertaining to the several parameters design, and it should be determined first to calculate the power of the turbine. There is hub and tip turbine diameter, that is determined as $60 \mathrm{~mm}$ and $200 \mathrm{~mm}$, water flow speed $1 \mathrm{~m} / \mathrm{s}$, design efficiency more than $50 \%$ and then turbine material is planned to use aluminum alloy.

From the calculation results obtained, water energy resources with an efficiency of 50\% are 295 watts, whereas the water speed on the turbine blade is $2.4 \mathrm{~m} / \mathrm{s}$. These conditions are enough to reach the target of the electrical power to be produced and water speed is still below critic speed so the fluid flow is still laminar flow.

By calculating the specific speed of the turbine at $500 \mathrm{rpm}$, the Specific Runner Speed (Ns) is $358.06 \mathrm{rpm}$. From the results obtained by the type of turbine that is suitable is the type of Kaplan. With the calculation of the velocity triangle, the blade inlet angle ( $\beta 1)$ is 80 degrees, the blade exit angle ( $\beta 2)$ is 58 degrees and the attack angle $(\xi)$ is 4 degrees, so the power produced by the turbine is 137 Watts. The power is good enough to produce an electric power target of 100 watts.

The flow passing through the turbine blade produces the blade particular forces. There are the lifting forces (FL) of $72.85 \mathrm{~N}$ and the water resistance (FD) of $310.59 \mathrm{~N}$ with the lift coefficient (CL) of (0.44) and drag coefficient is (0.95). The greater force is a water resistant force in the direction of the water flow. The force that occurs in the turbine produces a torque on the blade of $1.91 \mathrm{Nm}$. The torque is relatively large enough to rotate the load on the generator.

Torque of the runner must be transferred to the turbine shaft. Pin used to combine hub runner and shaft turbine. The hub diameter is $60 \mathrm{~mm}$ and the tip diameter is $217 \mathrm{~mm}$. These dimensions are close to the dimensions of the design specification.


Figure 4: Dimension of Rotor Blade Picohydro.

The next step is to calculate the strength that occurs in the turbine blade. Calculation of stress is used a simulation approach by using software. The forces that occur in the blade, as obtained in the previous calculation are $310.59 \mathrm{~N}$. From the simulation results, the voltage that occurs for the thickness of the turbine blade by $2 \mathrm{~mm}$ is $5.9 \mathrm{MPa}$, so it is quite safe to use aluminum alloy T6 material that have yield strength of $240 \mathrm{MPa}$. 




Figure 5: Von Misses Stress of Rotor Blade Picohydro.

From the simulation results, the maximum stress occurs in the area between the hub and turbine blade rotors, so that the area should be given a greater thickness than the turbine blade tip.

\section{CONCLUSIONS}

Runner turbine design has been accomplished, the type of blade used is Kaplan turbine, the blade and hub diameter is 217 $\mathrm{mm}$ and $60 \mathrm{~mm}$. The maximum stress from simulation obtained is 5,9 MPa, theis occurs in the area between the hub and turbine blade rotors. Runner suitable thickness is $2 \mathrm{~mm}$ for aluminum Alloy material used.

\section{ACKNOWLEDGEMENTS}

The authors wish to gratefully acknowledge Ristekdikti, who supported this research.

\section{REFERENCES}

1. Bhumkittipich, P., \& Bhumkittipich, K. N. (2013). Performance Study of Micro Hydro Turbine and PV for Electricity Generator, Case Study: Bunnasopit School, Nan Province, Thailand. 10th Eco-Energy and Materials (pp. 235 - 242). Elsevier.

2. BPS. (2016). Sub directorate of Statistical Compilation and Publication. Jakarta, West Java, Indonesia: BPS Statistic Indonesia.

3. DEN. (2014). Outlook Energi Indonesia 2014. Jakarta: Dewan Energi Nasional Republik Indonesia.

4. Erinofiardi, Gokhale, P., Date, A., Akbarzadeh, A., Bismantolo, P., Suryono, a. F., et al. (2017). A review on micro hydropower in Indonesia. first Internasional conference on Energy and Power (pp. 316-321). Melbourne: Elsevier.

5. ESMAP. (2007). Technical and Economic Assessment of Off Mini-grid and Grid Electrification echnologies. ESMAP.

6. Grant, I. (2007). Very Simple Kaplan Turbine Design. School Of Engineering : Durham University.

7. Hartawan, L., Rusirawan, D., Shantika, T., \& Farkas, I. (2018). Wireless monitoring system for mobile hybrid PV - PICO hydro power plant using nRF24LO1 and Arduino. 24th WORKSHOP ON ENERGY AND ENVIRONMENT, (p. 12). Gödöllö, Hungary.

8. Jigar K. Parmar, Sunny K. Darji \& Gajendra R. Patel, “Fuzzy Based MPPT Controller of Wind Energy Conversion System using PMSG”, International Journal of Electrical and Electronics Engineering (IJEEE), Vol. 7, Issue 3, pp.17-30 
9. Nasir Ul Rasheed Rathe, Sheen c Moses, S K Singh, Umakanta Sahoo \& Umair Nazir, "Characterization and Evaluation of Solar-Biomass Hybrid Model Based on Thermodynamic Analysis to run a Thermal Power Plant”, IMPACT: International Journal of Research in Engineering \& Technology, Vol. 6, Issue 1, pp. 1-14

10. Nugraha, I. N., \& Waluyo, S. (2013). Penerapan Dan Analisis Pembangkit Listrik Tenaga Pikohidro Dengan Turbin Propeller Open Flume TC 60 Dan Generator Sinkron SatuFasa 100 VA. Elkomika, 1 (4).

11. P. Senthilkumar \& G. Sankaranarayanan, "Production of Waste Polyethylene Bags in to Oil and Studies Performance, Emission and Combustion Characteristics in Di Diesel Engine”, BEST: International Journal of Humanities, Arts, Medicine and Sciences (BEST: IJHAMS), Vol. 3, Issue 10, pp. 149-158

12. Phrakonkham, S., Remy, G., Diallo, D., \& Marchand, C. (2012). Pico vs Micro Hydro based Optimized Sizing of a Centralized AC Coupled Hybrid Source for Villages in Laos,. Elsevier Ltd.

13. Ratnata, I. W., Sumarto, S., \& Saputra, W. S. (2018). Prototype of Pico Hydro - Solar Photovoltaic Hybrid System. (p. 384). IOP Conf. Series: Materials Science and.

14. Shantika, T., \& Hartawan, l. (2017). perancangan Konsep Pembangkit Listrik Hybrid Solar PV-Picohydro. Seminar Nasional Rekayasa dan Aplikasi Teknik Mesin (pp. 16-24). Bandung: Proceeding.

15. Shantika, T., \& Hartawan, L. (2018). Permanent Magnet Generator Design and Testing for hybride PV-Picohydro Power Plant. IJMET, 9 (11), 1167-1175.

16. Simpson, R., \& Williams, A. (2011). Design Of PropellerTurbines for Picohydro. University of Nottingham.

17. Sopian, K., \& Razak, J. (2009). Pico Hydro: Clean Power From Small Streams. Proceedings of the 3rd WSEAS Renewable Energy Sources.

18. V. Ramudu, U. Sudhakar \& P. Sadanandam, "Hydro Dynamic Performance of Francis Runner", International Journal of Mechanical Engineering (IJME), Vol. 3, Issue 6, pp. 1-10

\section{AUTHORS PROFILE}

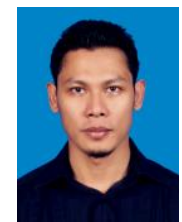

Tito Shantika, Born in Purwakarta, West Java, Indonesia, on June 10, 1979. In 1998, he graduated from the Institut Teknnoogi Nasional Bandung majoring in mechanical engineering, a research that was carried out concentrating on the design process, especially the design of coal briquettes machines. After graduating with a degree in 2002, he then worked in a ceramic company in Tangerang, Indonesia. In 2005, he continued his master's school at Universiti Kebangsaan Malaysia majoring in Department of Engineering, the research conducted was Analysis of flow on the Flowmeter turbine rotor using CFD. after graduating a master in 2006 became a lecturer at the Bandung National Institute of Technology until at present. Besides as a lecture, he is also a practicing instructor at the Laboratory of simulation and computational design. The research being carried out at present is the development of renewable energy hydro power, especially for picohydro hydroelectric power plants. Several grants have been obtained from both the Institute internally and from the Ministry of Research, Technology and Higher Education (Ristekdikti), grants with high expectations, namely from the Ministry of Research and Technology Republic of Indonesia with the National Strategic Grant scheme for two years. From this 
research several national journals and international journals have been produced. In addition to being a mechanical expert, he is also a consultant for several national companies, such as the Suralaya PLTU, PLN, the Ministry of industry, ect. In supporting the professionalism of lecturers, so far it still active role as an assessor in the certification of experts and skilled workers in the Institute of Construction Services development (LPJK), West Java Indonesia.



Tri Sigit Purwanto, Born on March 17th 1977, studied at the Bachelor Degree Program in Mechanical Engineering Department, National Institute of Technology. After graduating in 2001, he continued his study program in the Master in Thermo-Fluid Energy Conversion of Mechanical Engineering Department, Bandung Institute of Technology, after graduating and became a permanent lecturer at the Bandung National Institute of Technology until now. Association of expertise at ASHRAE (American Society of Heating, Refrigeration and Air-Conditioning Engineers) and PII (Indonesian Engineers Association). The research being carried out is the development of governors in mini hydro power plants. Aside from being a lecturer, he is also active as a mechanical expert in the field of Basic Design, feasibility study preparation reports and FEED preparation reports of steam turbine power plants, as well as Remaining Life Assessment and Risk Based Inspection of steam turbine power plants.

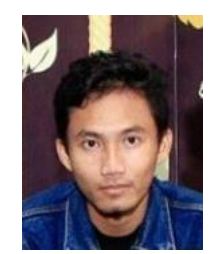

Martin Garnida, Born in Cilacap, 6 May 1992, is a student who has completed an undergraduate program at the Bandung National Institute of Technology. He is the best graduate of mechanical engineering major at the Bandung Institute of Technology. research carried out is to design a runner blade angle with a theoretical approach. 